van strafvordering zich tegen teruggave indien niet hoogst onwaarschijnlijk is dat de strafrechter, later oordelend, de verbeurdverklaring of onttrekking aan het verkeer van het voorwerp zal bevelen, al dan niet naar aanleiding van een afzonderlijke vordering daartoe als bedoeld in artikel $36 \mathrm{~b}$ lid 1 onder $4^{\circ} \mathrm{Sr}$ in verbinding met artikel $552 \mathrm{f} \mathrm{Sv}{ }^{26}$ De rechtbank heeft in de onderhavige zaak bij beschikking van 28 mei 2019 het beklag op grond van artikel 552a Sv tegen de inbeslagneming van dertien gegevensdragers (waaronder een gps-tracker) onder de klager gegrond verklaard per 28 juni 2019, indien daarover op die datum door het openbaar ministerie nog geen beslissing tot teruggave is genomen. Het onderzoek duurde de rechtbank kennelijk te lang, waardoor het openbaar ministerie als het ware nog een maand aan 'onderzoeksbelang' gegund kreeg:

'Hetgeen van de zijde van het openbaar ministerie is aangevoerd rechtvaardigt naar het oordeel van de rechtbank niet veel langer de conclusie dat het belang van strafvordering zich in dit geval verzet tegen de beëindiging van het beslag. Hoewel een groot aantal gegevensdragers in beslag is genomen en het begrijpelijkerwijs veel tijd kost om alles te doorzoeken is de rechtbank van oordeel dat het belang van klager bij teruggave van de gegevensdragers thans, na een halfjaar, zwaarder moet wegen. De rechtbank stelt een termijn van één maand waarbinnen het onderzoek dient te worden afgerond. De rechtbank zal het klaagschrift dan ook per 28 juni 2019 gegrond verklaren ten aanzien van de gegevensdragers waarover op 28 juni 2019 door het OM nog geen beslissing is genomen en de teruggave daarvan gelasten.'

Het middel van het openbaar ministerie klaagde onder meer dat het oordeel van de rechtbank dat het belang van de klager bij teruggave van dertien in de beschikking van de rechtbank vermelde gegevensdragers 'thans, na een half jaar', zwaarder moet wegen dan het belang van strafvordering, zonder nadere motivering, die ontbreekt, niet begrijpelijk is. Het openbaar ministerie had hiermee een punt. De rechtbank erkent namelijk dat er nog een onderzoeksbelang aanwezig is. Dan kan een klaagschrift enkel gegrond worden verklaard wanneer voortduren van het beslag in strijd zou zijn met de proportionaliteit en subsidiariteit. De omstandigheden van het geval kunnen immers meebrengen dat de rechter bij de beoordeling van een beklag over inbeslagneming ter motivering van zijn beslissing ervan blijk dient te geven te hebben onderzocht of er een redelijke verhouding bestaat tussen het belang van de strafvordering enerzijds en de belangen van de klagers anderzijds. Verklaart de rechtbank het beklag gegrond omdat voortduring van het beslag in strijd zou zijn met de eisen van proportionaliteit, dan dient de rechtbank haar oordeel wel toereikend te motiveren. Het gaat dan - anders gezegd - om uitzonderlijke gevallen die goed moeten worden gemoti- veerd. Dat is hier niet gebeurd. De rechtbank gaf geen inzicht waarom - anders dan het openbaar ministerie kennelijk meende - het onderzoek naar haar oordeel binnen een maand (wel) afgerond zou kunnen zijn en waarom geen genoegen kan worden genomen met de stelling van de officier van justitie dat het beslag wordt opgeheven zodra het onderzoek daaraan is afgerond. Ook had de rechtbank niet voldoende kenbaar gemaakt in welk belang de klager precies wordt getroffen en waarom het beslag na een halfjaar zo onevenredig zwaar drukt op de klager dat dit (niet nader omschreven) belang zwaarder moet wegen dan het belang van strafvordering. Daar komt nog bij dat de wet niet voorziet in een voorwaardelijke last tot teruggave. De Hoge Raad oordeelde dat een concrete en nauwkeurige belangenafweging toegespitst op de klager ontbrak in de beschikking van de rechtbank en achtte het middel gegrond. Met betrekking tot die voorwaardelijke last tot teruggave overweegt de Hoge Raad nog het volgende:

'Naar aanleiding van de gegrondverklaring door de rechtbank van het beklag ten aanzien van de hierboven genoemde goederen "per 28 juni 2019" en het gelasten van de teruggave daarvan aan de klager "indien daarover op 28 juni 2019 door het OM nog geen beslissing is genomen" merkt de Hoge Raad nog het volgende op. De wet voorziet niet in de mogelijkheid van een voorwaardelijke beslissing over strafvorderlijk inbeslaggenomen voorwerpen. Is de rechter van oordeel dat het belang van strafvordering zich (nog) verzet tegen de teruggave van de inbeslaggenomen voorwerpen, dan dient hij het klaagschrift waarin de teruggave van die voorwerpen wordt verzocht ongegrond te verklaren. Is daarvan geen sprake, dan dient in de regel teruggave te worden gelast (vgl. HR 12 november 2019, ECLI:NL:HR:2019:1692).'

\section{NTS 2020/39}

\section{HR 4 februari 2020, 18/05488, ECLI:NL:HR:} 2020:190

\footnotetext{
Aanhoudingsverzoek niet gemachtigde raadsman voorafgaand aan tz. per e-mail gedaan op de grond dat hij verdachte niet kan bereiken door Hof afgemezen o.g.v. overmeging dat formeel gezien geen sprake is van aanhoudingsverzoek. Heeft Hof verzuimd uitdrukkelijk en gemotiveerd te beslissen op aanhoudingsverzoek?
} 


\section{Aantekening redactie}

Op 7 december 2018 heeft het hof aanstonds uitspraak gedaan en de verdachte op de voet van artikel 416 lid 2 Sv niet-ontvankelijk verklaard in het hoger beroep (geen schriftuur van grieven ingediend). Dit deed het hof na te hebben geoordeeld dat 'formeel gezien geen sprake is van een aanhoudingsverzoek'. Dit betrof een e-mailbericht van de raadsman van 6 december 2018 inhoudende de mededeling dat hij niet gemachtigd is en dat hij een aanhoudingsverzoek doet:

'Ik probeer mijn cliënt al de hele week te bereiken maar hij laat niets van zich horen. Zijn telefoon staat uit en dat al een week lang. Dat is niets voor mijn cliënt. Zijn familie heeft mij vandaag laten weten zich ernstige zorgen te maken en ik heb hen zojuist geadviseerd naar het politiebureau te gaan om aldaar aangifte te doen van vermissing. Nogmaals, mijn cliënt [verdachte] is normaliter voor mij altijd goed bereikbaar en ook ik maak me dus een beetje zorgen. Wat hier verder van zij; als niet gemachtigd raadsman kan ik morgen niet het woord ter verdediging voeren, enkel een verzoek tot aanhouding doen. Dat doe ik dan ook bij dezen: ik weet zeker dat cliënt namelijk gewoon gebruik wil maken van zijn aanwezigheidsrecht, temeer nu het zijn uitdrukkelijke wens was om tegen het vonnis hoger beroep in te stellen daar hij het niet eens is met de bewezenverklaring van feit 1 . De reden dat ik u dit aanhoudingsverzoek per mail stuur is dat ik u tijdig over dit aanhoudingsverzoek en de onderliggende strubbelingen wil informeren. $U$ en uw collega's worden morgenochtend hiermee dan ook niet overvallen. Ik zal zelf morgen dus niet zelf aanwezig zijn.'

Het oordeel van het hof rust dus op de veronderstelling dat de zittingsrechter niet behoeft te beslissen op een verzoek tot aanhouding dat niet ter zitting is gedaan. Dat oordeel is volgens de Hoge Raad onjuist. Het verzoek tot aanhouding dat de raadsman van de verdachte bij e-mailbericht van 6 december 2018 heeft gedaan, is een verzoek op grond van artikel $278 \mathrm{lid} 3 \mathrm{~Sv}$ in verbinding met artikel 331 lid $1 \mathrm{~Sv}$ en artikel 415 lid 1 Sv. Op een dergelijk verzoek moet ter terechtzitting worden beslist nadat het openbaar ministerie omtrent dit verzoek is gehoord. Verzuim om op een dergelijk verzoek te beslissen is met nietigheid bedreigd. ${ }^{27}$ Een verzoek tot aanhouding van het onderzoek ter terechtzitting kan dus op de terechtzitting worden gedaan door de verdachte of zijn raadsman die daartoe door de verdachte op grond van artikel $279 \mathrm{~Sv}$ is gemachtigd. Ook de raadsman die niet is gemachtigd tot het voeren van de verdediging van de verdachte die op de terechtzitting niet is verschenen, kan daar een verzoek doen tot aanhouding van het onderzoek op de terechtzitting voor zover dat verzoek wordt gedaan met het oog op de effectuering van het

27. HR 11 oktober 2005, ECLI:NL:HR:2005:AT5663 en HR 10 oktober 2017, ECLI:NL:HR:2017:2579. aanwezigheidsrecht van de verdachte of ten behoeve van het alsnog verkrijgen van de in artikel 279 lid $1 \mathrm{~Sv}$ bedoelde machtiging. Overeenkomstig artikel 329 en $330 \mathrm{~Sv}$ wordt beslist op het verzoek nadat het openbaar ministerie daaromtrent is gehoord. Wanneer het verzoek om aanhouding al vóór de terechtzitting wordt gedaan, kan om praktische redenen door (de voorzitter van) het gerecht ook al vóór de terechtzitting aan degene die om aanhouding verzoekt, worden kenbaar gemaakt hoe het voorlopige oordeel van het gerecht omtrent het verzoek luidt. De uiteindelijke beslissing dient evenwel steeds op de terechtzitting te worden genomen en in het procesverbaal van die terechtzitting te worden vastgelegd. Het hof had dus een afweging moeten maken tussen alle bij aanhouding van het onderzoek ter terechtzitting betrokken belangen. Het gaat daarbij om het belang van de verdachte bij het kunnen uitoefenen van zijn in artikel 6 lid 3 onder c EVRM gewaarborgde aanwezigheidsrecht - waaronder het recht om zich in zijn afwezigheid ter terechtzitting door een daartoe uitdrukkelijk gemachtigde raadsman te doen verdedigen - en, kort gezegd, het belang dat niet alleen de verdachte maar ook de samenleving heeft bij een doeltreffende en spoedige berechting. Van deze afweging, waarbij de aan het verzoek tot aanhouding ten grondslag gelegde gronden moeten worden betrokken, dient de rechter in geval van afwijzing van het verzoek blijk te geven in de motivering van zijn beslissing. ${ }^{28}$

NTS 2020/40
2020:192

Poging doodslag te Groningen door met mes in hals van huisgenoot te snijden, nadat broer van verdachte's nachts met deze persoon in gevecht is gemeest. Noodmeer(exces)?

\section{Aantekening redactie}

De verdachte is door het hof wegens 'poging tot doodslag', veroordeeld tot een gevangenisstraf voor de duur van eenentwintig maanden, waarvan zeven maanden voorwaardelijk met een proeftijd van twee jaar. Het middel klaagde over de verwerping door het hof van het beroep op noodweer en noodweerexces. De feiten zijn als volgt. De verdachte en zijn één jaar jongere broer, tevens medeverdachte, woonden ten tijde van het ten 